Jurnal Pena Sains Vol. 6, No. 1, April 2019

p-ISSN: 2407-2311

e-ISSN: 2527-7634

\title{
DEVELOPMENT OF INTEGRATED SCIENCE DIGITAL MODULE BASED ON SCIENTIFIC LITERACY
}

\author{
Retna Kusuma Astuti ${ }^{1}$ and Muriani Nur Hayati ${ }^{2}$ \\ ${ }^{1}$ Program Studi Pendidikan IPA, Universitas Pancasakti Tegal, 52122, Indonesia \\ retnakusuma06@gmail.com \\ ${ }^{2}$ Program Studi Pendidikan IPA, Universitas Pancasakti Tegal, 52122, Indonesia \\ widira_alkhansa@gmail.com
}

Accepted: October 30, 2018

Published: April 30, 2019

DOI: http://doi.org/10.21107/jps.v6i1.5233

\begin{abstract}
Student quality of Science education program in the University of Pancasakti Tegal which is prepared to be science teacher candidates in junior high school in the future needs to be enhanced, because they must improve student scientific literacy ability. Students were expected to have scientific literacy competence and advanced in internet technology. Thus, research objectives were determining validity, reading level, and module effectiveness. It was development research. Subject of this reasearch is Students of Science Education study program in University of Pancasakti Tegal, semester IV, 2017/2018 academic year. The first step was fulfilling validity criteria, reading level and then trying out to determine learning effectiveness. Data analyze used judgment expert method, t-test and gain test. It concluded that the Integrated Science digital module based on scientific literacy was valid for learning with a score of 26 (high), easy understanding in reading level, it was useful to enhance cognitive learning outcome students that could be seen from classical learning outcome total of experiment class of $82.35 \%$ and control class of $52.94 \%$. Gain result and t-test showed that there was a significant difference between experiment class and control class, it was 4.057, gain test for experiment class was $g=0.31$ and control class of $g=0.24$.
\end{abstract}

Keywords: scientific literacy, validity, effectiveness, digital module, Integrated Science.

\footnotetext{
${ }^{1}$ Corresponding Author
} 


\section{Development of Integrated Science Digital Module}

\section{Introduction}

Science education has a role in everyday life. Science education encourages students to think about natural phenomena or phenomena with scientific methods such as scientists and prepares students to become citizens who are responsible for the phenomena around, for example, global warming or others (Sahlan, 2013). If students are not provided with scientific education needs, it will harm the environment. Someone who does not literate science will tend to harm themselves and others around him (Lukum, 2015).

The world enters the industrial revolution era 4.0 or the fourth world industrial revolution where the basis in human life is information technology (Kemenristekdikti, 2018). The use of the science of communication and technology plays a very vital role, including in the field of education as shown in changes in the style of life in the 21st century (Burhan, 2016). Therefore, the relevance of education and work needs to be adjusted to the development of the era and science and technology. The National Medium-Term Development Plan is by the mandate context of Presidential Regulation No. 2 of 2015 that the role of science and technology is expected to contribute significantly to the national economy.

Indonesia as a great nation must be able to develop a culture of literacy as a prerequisite for 21 st-century life skills through integrated education, from families, schools, to communities (Kemendikbud, 2017). Thus, in the context of global competition and the rapid development of information technology, national competitiveness can increase with the support and role of universities (Subekti, et al, 2018). The main success of technology integration in education comes from curriculum content, learning processes, and the use of technology in education.

The success of technology integration in education comes primarily from curriculum content, learning processes, and the use of technology in education. Literacy comes from the word literate which means literacy, while science defined as natural science. The description implies that scientific literacy is not blind to science. Based on the results of the scientific literacy survey conducted by PISA in 2009 (PISA, 2012), Indonesia experienced a rating increase from its original position which was ranked second lowest to sixth place above it, but the rise in achievement was still below the average of countries The OECD is equal to 493 . The results of this achievement indicate that the average scientific ability of Indonesian students is always at the stage of the ability to recognize, identify and remember scientific knowledge in accordance with simple facts, while the ability to link scientific interactions, communicate them in society, apply concepts science concepts that are more abstract and complex are still lacking.

Universities, nowadays get input from students who are born, grow and develop in a digital environment (Yanti, 2016). Therefore, old knowledge about literacy "reading, writing, and counting" needs to be upgraded to digital literacy. Digital literacy is as essential as reading, writing, arithmetic, and another discipline, which digital literacy must understand is the important thing needed to participate in the modern world. Students need more learning that is supported by technological advances rather than knowledge that prioritizes general concepts. 
Fatkhurrohman \& Astuti (2017) stated that to become a professional and superior teacher in mastering science literacy, the quality of the Science Education Study Program students must prepare themselves carefully from the beginning of the lecture. Therefore, it is necessary to increase the mastery of scientific literacy, especially students of the Science Education Study Program, who will later assume the responsibility as a junior high school science teacher to develop students' literacy skills in school.

Integrated Science is one of the compulsory subjects in the Science Education Study Program curriculum at UPS-Tegal which weights two credits. The aims to develop a broader perspective on the concepts of science studies (Biology, Physics, and Chemistry), science issues in everyday life, defining the links between the three sciences (Biology, Physics, Chemistry) in an integrated manner to be packaged in one theme contextually. Increased scientific literacy skills also emphasized in this lecture.

During the educational activities of Science Education students at UPS-Tegal in the odd semester of the 2016/2017 academic year, according to the observation of Integrated Science lecturers, the application of student science literacy is still lacking. It can be seen from the learning outcomes, especially cognitive, that students only develop scientific literacy indicators in the form of science as the body of knowledge. The results of the research conducted by Rusilowati (2014) also stated that there was an imbalance between parts of the scientific literacy aspects that were studied in textbooks. The results of the study from Hayati (2017) also concluded that the science literacy of science teacher candidates in the Science Education Study Program at
UPS was still low. It can be shown from the nominal literacy level of $56.64 \%$, functional literacy of $26.40 \%$, conceptual literacy of $61.50 \%$, and multidimensional literacy of $50.20 \%$.

The use of internet technology aims to improve the aspects of scientific literacy in the form of interaction between science, technology, and society. The internet is not only for social and entertainment purposes but also for information in academic and scientific fields. The potential impact in the educational and scientific areas is as a provider of information that is easy and fast to access and can innovate in the learning process according to the development of internet technology (Dogruer \& Menevis, 2011).

The knowledge transfer during the learning process is often not optimal because of the amount of material that must be charged and the limited time in one semester. Even though students are also required to learn independently, especially in concepts that do not require complicated calculations. Students are expected to be able to learn whenever and wherever. It supports the learning process needed teaching materials in the form of modules.

Irwandani, et al. (2017) explained that the module is divided into two at this time, namely the print module and digital module. Interactive learning media can be displayed in digital modules. Implementation of the use of modules in learning can improve students' thinking skills and actively participate in exploring science (Matanluk, et al., 2013). In general, the use of internet technology in lectures that have not been optimal and especially in the Science Education Study Program, as well as the unavailability of Integrated Science modules. 
Development of Integrated Science Digital Module

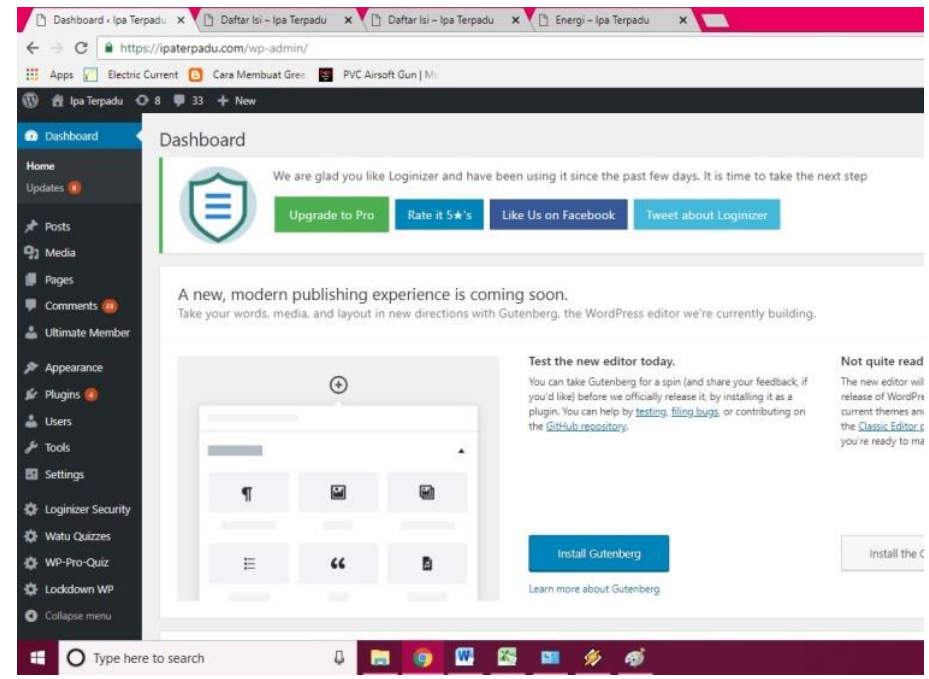

Figure 1. Display of Word press Dashboard

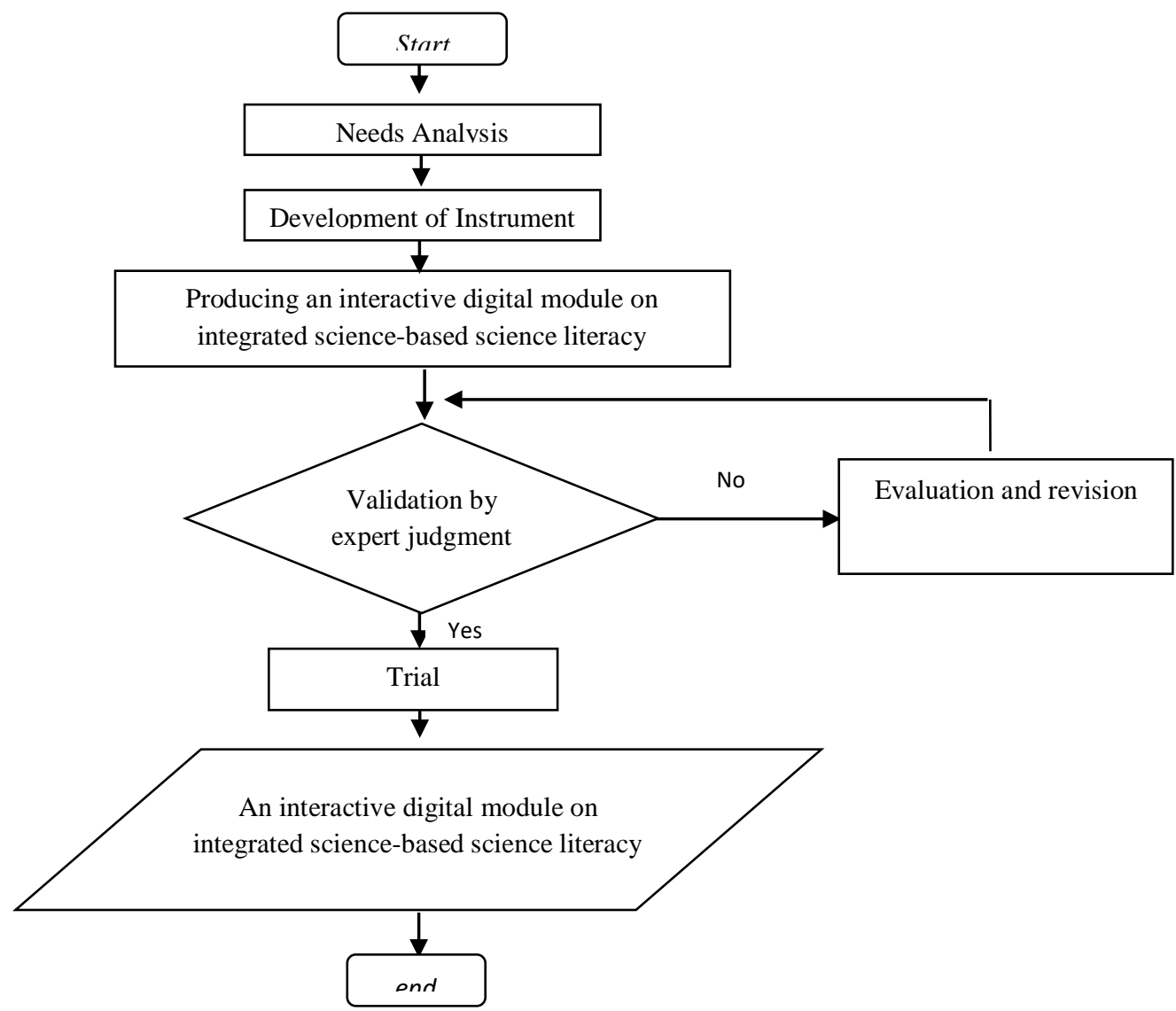

Figure 2. Flowchart Design Development of an interactive digital module on integrated science-based science literacy (Modification from Sadiman et al.1996) 


\section{Astuti and Hayati}

Based on this description, it is necessary to develop an integrated science module that can be accessed online which contains balanced scientific literacy indicators, namely integrated science digital module-based science literacy (see figure 1). The innovation of this research is the digital module that will be developed using an open source content management system that is used to build dynamic websites with Word Press. Module content can be formatted text material that equipped with scientific literacy indicators, web links, discussion topics, assignments, tests, and quizzes.

\section{Research Method}

The purpose of this study is to determine the validity, readability, and effectiveness of digital modules that have been developed. This research is a research and development in the form of an interactive digital module on integrated science-based science literacy. This research was conducted at Tegal Pancasakti University. The subjects of this study were 34 students of Science Education Study Program, semester IV, Academic Year 2017/2018. The steps of research and development are shown in Figure 2.

The trial uses Nonequivalent Control Group Design (Sugiyono, 2011) according to Table 1.

Table 1. Trial of Product

\begin{tabular}{cccc}
\hline Class & Pretest & Treatment & Posttest \\
\hline experiment & $\mathrm{O}_{1}$ & $\mathrm{X}_{1}$ & $\mathrm{O}_{2}$ \\
\hline Control & $\mathrm{O}_{1}$ & $\mathrm{X}_{2}$ & $\mathrm{O}_{2}$
\end{tabular}

$\mathrm{O} 1$ = pretest to measure the conceptual understanding of students

$\mathrm{O} 2=$ posttest to measure the conceptual understanding of students

$\mathrm{X} 1$ = treatment (applying integrated science digital modules based on scientific literacy)

$\mathrm{X} 2=$ treatment in the form of conventional learning
Data collection techniques include tests, observations, and documentation. The aspects assessed in testing the validity of digital modules have 8 aspects, namely content, rationality, characteristics, and conformity with curriculum, language, physical form, and flexibility. Each aspect was given a value of at least 1 and a maximum of 4 with the assessment categories in Table 2 .

Table 2. Assessment Scale of The Validity of Integrated Science Digital Module

\begin{tabular}{|c|c|c|}
\hline Category & Recommendation & Range of value \\
\hline $\begin{array}{l}\text { Excellent } \\
\text { validity }\end{array}$ & $\begin{array}{l}\text { Useable without } \\
\text { revision }\end{array}$ & $V>28$ \\
\hline $\begin{array}{l}\text { Good } \\
\text { validity }\end{array}$ & $\begin{array}{l}\text { Useable with minor } \\
\text { revision }\end{array}$ & $23<\mathrm{V} \leq 28$ \\
\hline $\begin{array}{l}\text { Fair } \\
\text { validity }\end{array}$ & $\begin{array}{l}\text { Useable with major } \\
\text { revision }\end{array}$ & $13<\mathrm{V} \leq 23$ \\
\hline $\begin{array}{l}\text { Poor } \\
\text { validity }\end{array}$ & unusable & $\mathrm{V} \leq 13$ \\
\hline
\end{tabular}

The technique of knowing the level of readability of instructional material texts, according to Sudijono (2008) can be calculated as follows:

Information:

$$
P=\frac{f}{N} \times 100 \%
$$

$\mathrm{P}=$ Percentage of assessment

$\mathrm{f}=$ scores obtained by students

$\mathrm{N}=$ overall score

Learning is said to be completed individually by meeting the minimum completeness requirements, namely, the value of student learning achievement reaches at least 56 or C. Classical completeness is obtained if less than $75 \%$ of students complete individually. To calculate classical completeness as follows:

$P=\frac{\sum \text { Number of Studens Completeness }}{\sum \text { Number of Students }} \times 100 \%$

$\mathrm{P}=$ The number of classical completeness 


\section{Development of Integrated Science Digital Module}

The significance level of differences in learning outcomes uses integrated science digital modules based on literacy science with modules in general. The effectiveness of digital modules can be seen from the significance level of differences in student learning outcomes by using science-based integrated science digital modules with ordinary modules using the t-test formula with polled variance (Sugiyono, 2004).

$$
\begin{gathered}
t=\frac{\bar{x}_{1}-\bar{x}_{2}}{s \sqrt{\frac{1}{n_{1}}+\frac{1}{n_{2}}}} \text { when } \\
s=\sqrt{\frac{\left(n_{1}-1\right) s_{1}^{2}+\left(n_{2}\right) s_{2}^{2}}{n_{1}+n_{2}-2}}
\end{gathered}
$$

$x_{1}=$ the average student learning outcomes that use integrated science digital modules based science literacy

$\bar{x}_{2}=$ the average student learning outcomes that do not use integrated science digital modules based science literacy

$\mathrm{s}_{1}{ }^{2}=$ variants of student learning outcomes that use integrated science digital modules based science literacy

$\mathrm{s}_{2}{ }^{2}=$ variants of student learning outcomes that do not use integrated science digital modules based science literacy

The price of the calculated value compared with the cost of the t-table with a significance level of $5 \%$. If it counts more than $\mathrm{t}$-table then the increase is significant.

This test is used to test the significance of the increase in cognitive learning outcomes between pretest, posttest and the ability to be independent with the gain formula. According to (Savinainen \& Scott, 2002) formulated as follows (Savinainen \& Scott, 2002).

$g=$ Size of factor $\mathrm{g}$

$$
g=\frac{\left\langle S_{\text {post }}\right\rangle-\left\langle S_{\text {pre }}\right\rangle}{100 \%-\left\langle S_{\text {pre }}\right\rangle}
$$

$\left\langle S_{\text {post }}\right\rangle=$ average of posttest score

$\left\langle S_{\text {pre }}\right\rangle=$ average of pretest score
Table 3. Classification of Factor (g)

\begin{tabular}{ll}
\hline Interval Factor $(\mathbf{g})$ & Criteria \\
\hline$>0,70$ & High \\
$0,3 \leq(\mathrm{g}) \leq 0,7$ & Moderate \\
$(\mathrm{g})<0,3$ & Low
\end{tabular}

\section{Result and Discussion}

It has become a common agreement, that information, communication, and technology (ICT) are important and vital in the economic and social development of a country. Pischetola \& Cattolica (2011) explain the impact of ICT on learning strategies that technologies in the 21 st century provide users with the best opportunities to improve distance, place, and meaning of learning. The emergence of Web 2.0 such as TV webcasting, blogging, social networks or Wikis has content facilities for sharing and collaboration, as well as communication such as cross-geography, time zones, and culture.

Literacy is not only described again as the ability to read, write (books, newspapers, magazines, or things that need paper), but also more related to the search for information from various sources to be understood functionally and eventually elaborated into knowledge. ICT has changed the information access landscape that integrates various types of literacy, which makes us more familiar as the ability to understand literacy. Furthermore, literacy is essential for evaluating and integrating information in a dual format through a computer. It is what Gilster \& Watson (1997) call the first time as digital literacy.

In this study, the development of an integrated science digital module based science literacy on the theme of Energy, Environment, and Pollution. The digital module is accessed online at http://www.ipaterpadu.com. The steps taken in the development phase of the digital 


\section{Astuti and Hayati}

module are the first needs analysis. It needs analysis activity is carried out with literature studies, namely by looking for the literature of reference journals and books, the latest websites. Then, the researcher conducted a field study to find out the initial information and identify the problems and set goals by interviewing students. The content in the integrated science digital module based on scientific literacy is consisting of four aspects of scientific literacy. It includes science as a body of knowledge (a body of knowledge), science as a way of investigating, science as a way of thinking ( way of thinking), and the interaction between science, technology, and society (interaction of science, technology, and society). The characteristics of integrated science literacy based digital science modules developed in this study have a ratio of four aspects of scientific literacy of 1: 1: 1: 1 . Some obstacles occur among them there are some students who are still having trouble accessing and managing time doing online assignments. The display of integrated science literacy digital science module can be seen in Figures 3, 4, 5, 6 and 7.

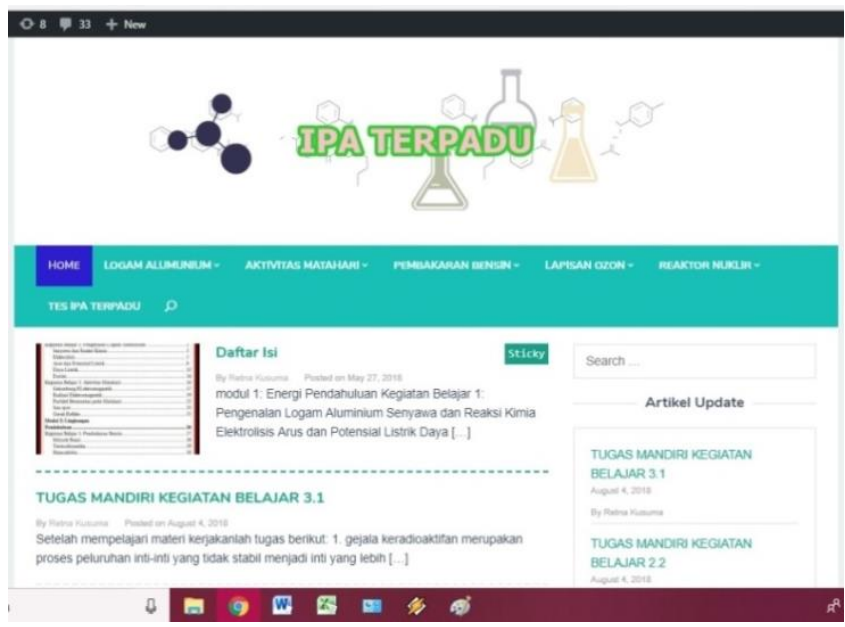

Figure 3. Initial display of the ipaterpadu.com digital module

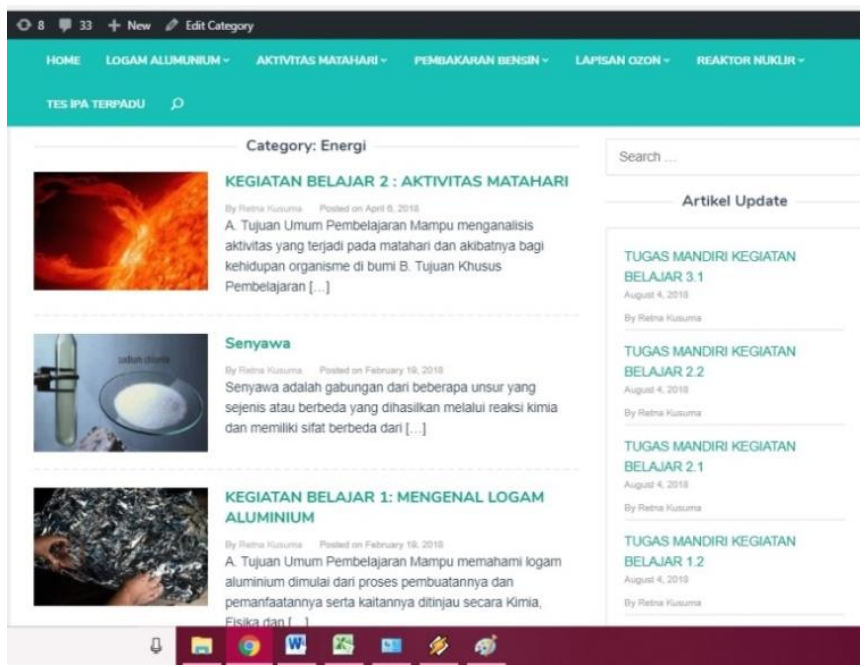

Figure 4. Display of material collections 


\section{Development of Integrated Science Digital Module}

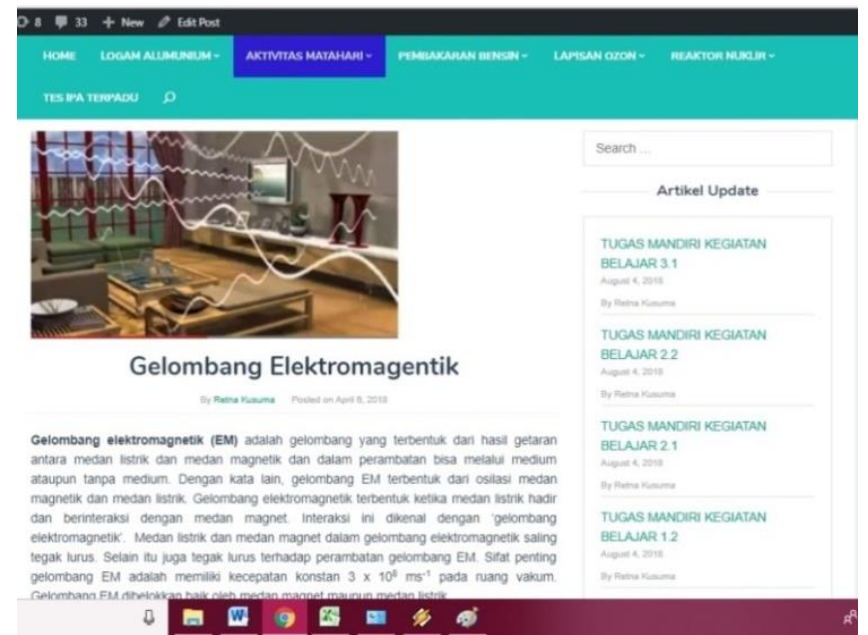

Figure 5. Display of one of the contents of the material

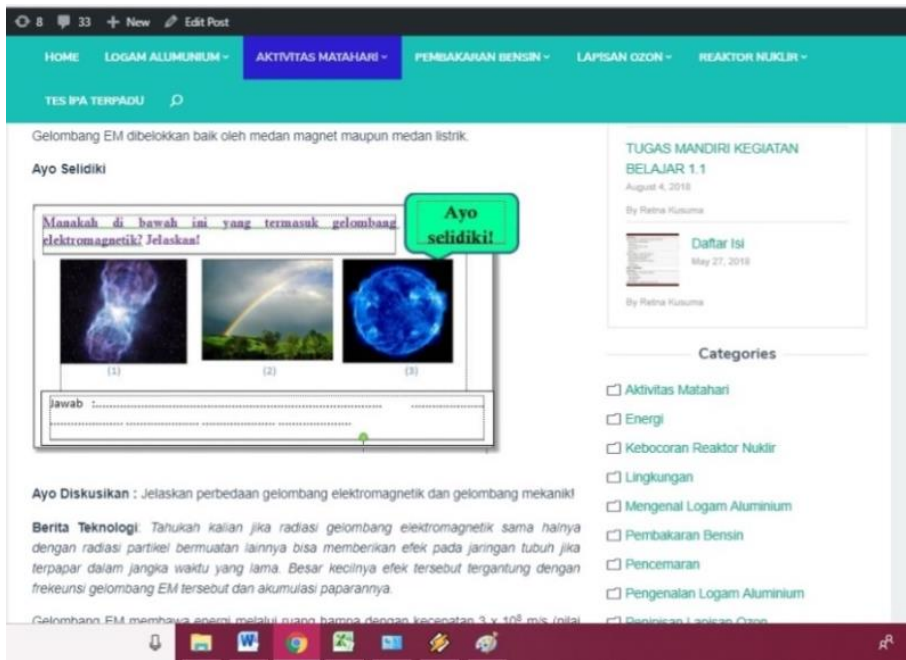

Figure 6. Display of one of the contents of the material

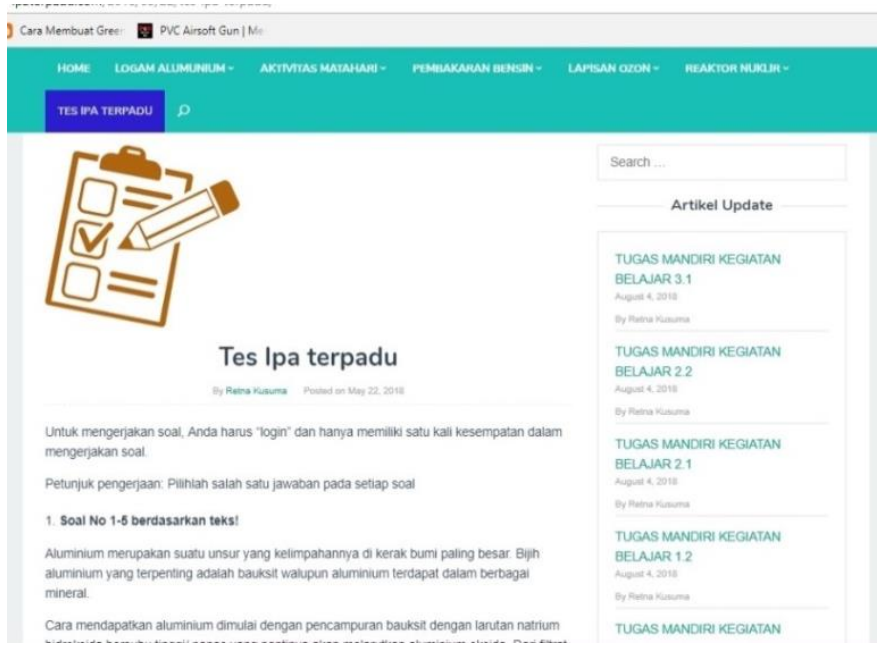

Figure 7. Display evaluation 


\section{Astuti and Hayati}

The results of the validator team's assessment of the integrated science digital module based on scientific literacy can be seen in Table 4.

Table 4. Recapitulation of module validation values

\begin{tabular}{llcccc}
\hline \multirow{2}{*}{ No } & \multirow{2}{*}{$\begin{array}{c}\text { Aspect of } \\
\text { Assessment }\end{array}$} & \multicolumn{4}{c}{ Score } \\
\cline { 3 - 6 } & & I & II & III & IV \\
\hline 1 & Objective & 4 & 3 & 3 & 4 \\
2 & Rational & 3 & 4 & 3 & 3 \\
3 & Module Content & 3 & 3 & 2 & 4 \\
4 & Characteristics & 2 & 3 & 3 & 3 \\
5 & Fitness & 3 & 4 & 3 & 4 \\
6 & Language & 3 & 4 & 3 & 4 \\
7 & Display & 2 & 4 & 3 & 4 \\
8 & Flexibility & 3 & 4 & 2 & 4 \\
\hline & Total Score & 23 & 29 & 22 & 30 \\
\hline & Average Score & \multicolumn{4}{c}{26} \\
\hline & category & \multicolumn{5}{c}{ Good Validity } \\
\hline
\end{tabular}

Testing the level of readability of the module uses quotes by imprinting the 10th word from the module. This test is a limited scale test, conducted on ten students in the sixth semester of the Science Education study program. The results test can be seen in Figure 8 and Table 5.

Table 5. Recapitulation Level of Readability

\begin{tabular}{ccc}
\hline No & Description & Level of Readability \\
\hline 1 & Minimal Score & $45 \%$ \\
2 & Maximum Score & $62 \%$ \\
3 & Average & $51,9 \%$ \\
\hline
\end{tabular}

Table 4 shows the acquisition of the average score of the module readability level of $51.9 \%$. It shows that the developed science literacy based digital science module which included in the category of teaching materials is easy to understand.

Based on the results of data analysis, it obtained if a valid module with high validity is equal to 26 and the level of readability of the module in the module criteria is understood. Based on the analysis of cognitive learning outcomes, namely the use of science-based Integrated Science science digital modules can improve cognitive learning outcomes of students of Science Education Study Program. It can be seen from the results of the gain test that the increase between the pretest and posttest scores in Table 8 of the experimental class is 0.31 and includes the moderate category, and the control class is 0.24 included in the low category.

The broad-scale test on module development in this study is by looking at the effectiveness of the module after it is applied. This large-scale test is carried out by giving digital modules to the experimental class as learning resources, while the control class not offered the module. The pretest cognitive learning outcomes of the experimental and control classes before being given treatment can be seen in Figure 9 and Table 6.

Table 6. Recapitulation of cognitive learning outcomes pretest in experimental and control classes

\begin{tabular}{llll}
\hline \multicolumn{1}{c}{ Class } & $\begin{array}{c}\text { Minimal } \\
\text { score }\end{array}$ & $\begin{array}{c}\text { Maximum } \\
\text { score }\end{array}$ & Average \\
\hline experiment & 60 & 83 & 75,82 \\
control & 37 & 90 & 64,18 \\
\hline
\end{tabular}

Posttest cognitive learning outcomes of the experimental and control classes after being given treatment can be seen in Figure 10 and Table 7.

Table 7. Recapitulation of posttest cognitive learning outcomes in the experimental and control classes

\begin{tabular}{lllll}
\hline Class & $\begin{array}{l}\text { Min } \\
\text { Score }\end{array}$ & $\begin{array}{l}\text { Max } \\
\text { Score }\end{array}$ & $\begin{array}{l}\text { Averag } \\
\text { e }\end{array}$ & $\begin{array}{l}\text { Classical } \\
\text { Mastery } \\
\text { Learning }\end{array}$ \\
\hline a & 73 & 91 & 83,29 & $82,35 \%$ \\
B & 60 & 90 & 72,94 & $52,94 \%$ \\
\hline a= experiment & & & \\
b = control & & &
\end{tabular}




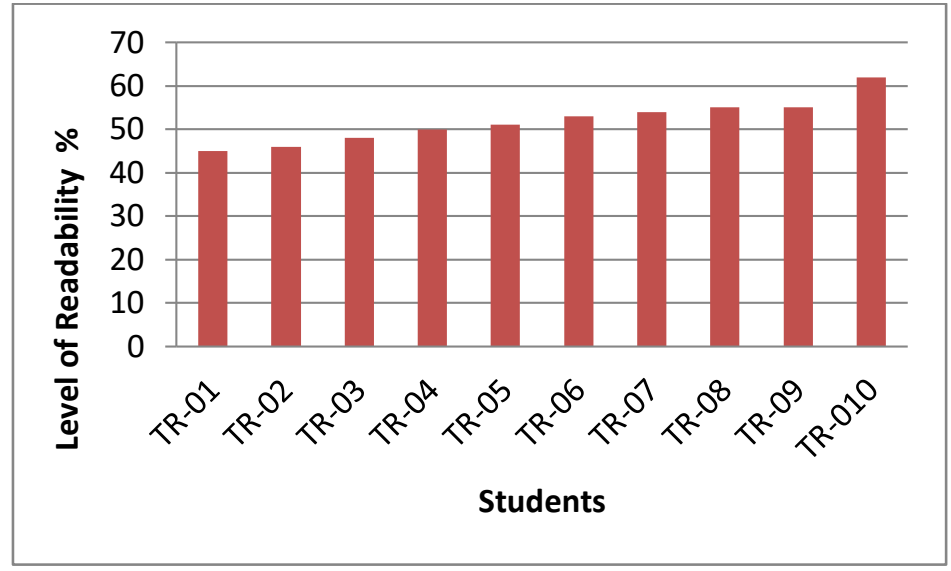

Figure 8. Graph of Readability Levels in the Module

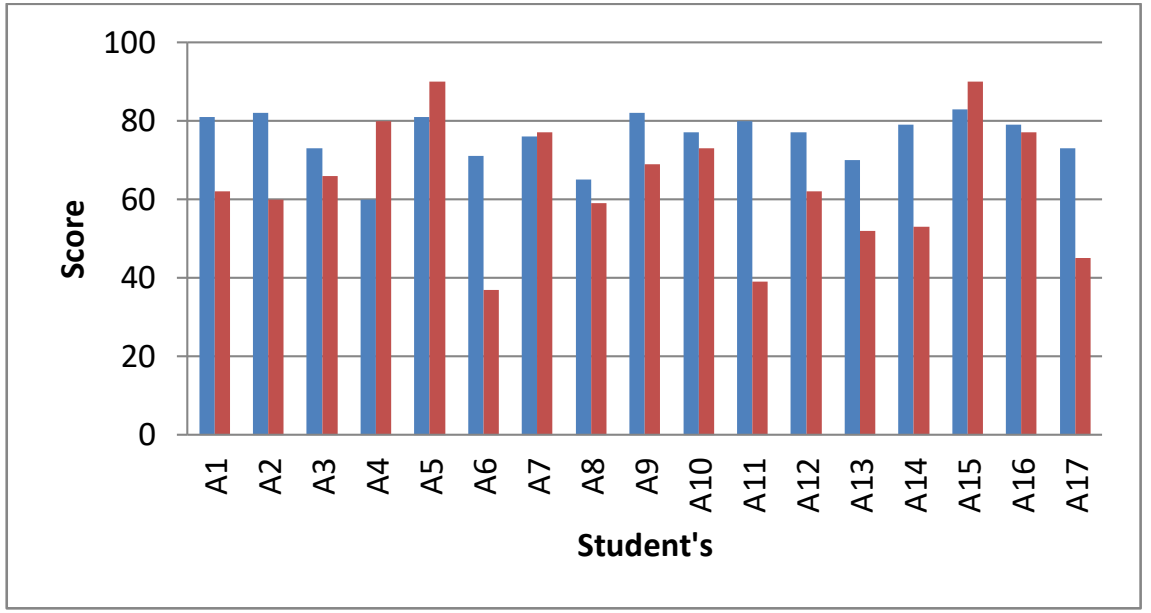

Figure 9. Graph of cognitive learning outcomes pretest in experimental and control classes

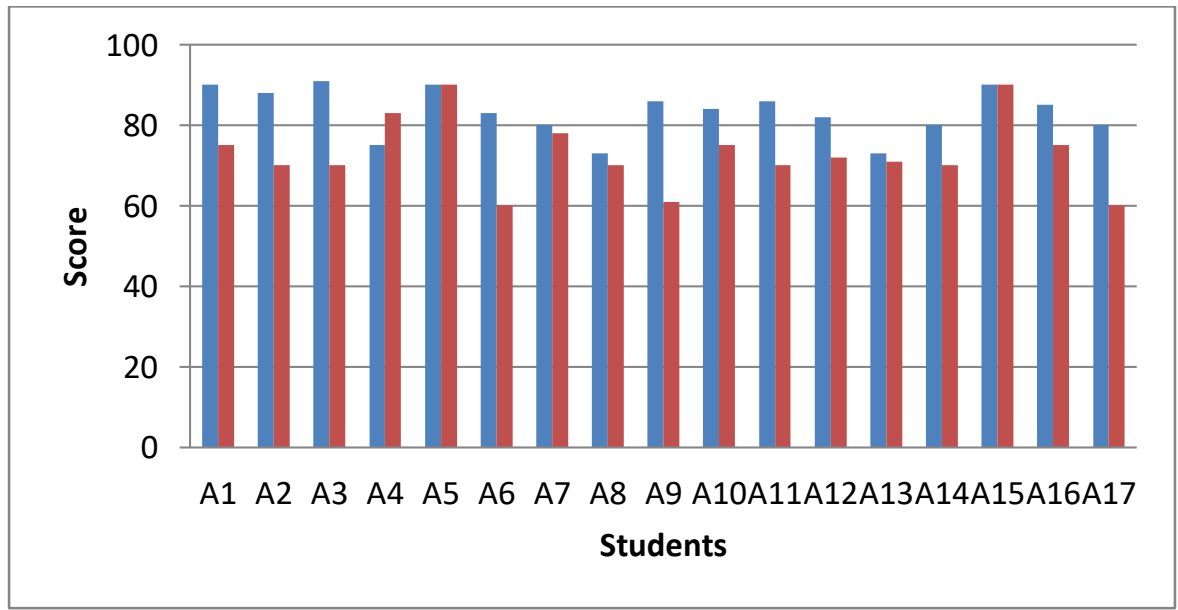

Figure 10. Graph of posttest cognitive learning outcomes experiment class and control 


\section{Astuti and Hayati}

Table 7 shows the acquisition of the average score of the experimental class of 83.29, while the addition of the average score of the control class is 72.94 . The experimental class obtained an average value higher than the control class. Besides, the acquisition of the classical completeness of the experimental class was $82.35 \%$, while the control class was $52.94 \%$. From these data, the acquisition of classical completeness in the experimental class is also higher than the control class. Based on the results of the gain test the experimental and control class cognitive learning outcomes can be seen in Table 8.

Table 8. Recapitulation of gain test on cognitive learning outcomes in the experimental and control classes

\begin{tabular}{lcccc}
\hline Category & \multicolumn{2}{c}{ Experiment Class } & \multicolumn{2}{c}{ Control Class } \\
\hline & Pretest & Posttest & Pretest & Posttest \\
\hline Lowest & 60 & 73 & 37 & 60 \\
$\begin{array}{l}\text { Score } \\
\text { Highest }\end{array}$ & 83 & 91 & 90 & 90 \\
$\begin{array}{l}\text { Score } \\
\text { Average }\end{array}$ & 75,82 & 83,29 & 64,18 & 72,94 \\
Gain & \multicolumn{2}{c}{0,31} & \multicolumn{2}{c}{0,24} \\
Category & \multicolumn{2}{c}{ Moderate } & \multicolumn{2}{c}{ Low } \\
\hline
\end{tabular}

Based on Table 8 , it was seen that the increase in experimental class cognitive learning outcomes was higher than the control class in the medium range, while the control class was low. Judging from the results of the classical completeness test the experimental class is also better than the control class which is $83.35 \%$, and the control class is 52.94 . It is quite good in terms of improving cognitive learning outcomes by applying integrated science digital modules based science literation. The increase in learning outcomes is also due to the learning process in the class presented with digital media such as computers and smartphones with the support of material content that is more interesting, interactive and can be accessed repeatedly whenever students learn. This digital module accessed online integrated into elearning learning. It certainly has an impact on increasing understanding, knowledge of prospective science teacher students, especially the experimental class given by the treatment. In accordance with what was stated by Eshet-alkalai (2004), that digital literacy includes not only the ability to use and operate software or digital equipment but also a variety of complexes of cognitive, motoric, social and emotional skills, in which users need effectiveness in a digital environment, such as "reading" commands from graphical displays. Digital literacy also allows measuring the quality of learning work in a digital environment, providing universities and developers to design a digital environment effectively.

The significance level of differences in cognitive learning outcomes using integrated science digital modules based scientific literacy with modules in general can be seen from the results of the t-test in Table 9.

Table 9. T Test Results in Experiment and Control Classes

\begin{tabular}{cccc}
\hline $\mathbf{T}_{\text {count }}$ & $\mathbf{D k}=\mathbf{n}_{\mathbf{1}}+\mathbf{n}_{\mathbf{2}} \mathbf{- 2}$ & $\mathbf{T}_{\text {table (0,975)(32) }}$ & Criteria \\
\hline 4,057 & 32 & 2,445 & Ha accepted if $t_{\text {count }}>t_{\text {table }}(1-\propto)\left(n_{1}+n_{2}-2\right)$ \\
\hline
\end{tabular}

The results of the T-test show that the t-count is in the Ha acceptance area, it can be concluded that the experimental group's learning outcomes are better than 


\section{Development of Integrated Science Digital Module}

the control group with a significant difference in the increase.

In addition, the application of digital modules can also be interspersed with discussions and presentations in front of the class and independently, and of course, students work on Quiz online with limited time during the process. By the opinion (Jethro et al. (2012) e-learning can be accessed anytime and anywhere. This learning model is quite popular in the world of education because it can potentially be accessed anywhere, anytime to improve learning outcomes. Olteanu et al. ( 2014) revealed that with the use of the Integrated Science module, there was an impressive implementation of student feedback. After the introduction of the Integrated Science module, awareness in the involvement of science in everyday life has increased from the viewpoint of students. The Integrated Science Module helps learners to understand the different concept of material and make connections in a discussion of a particular theme.

\section{Conclusion}

Finally, it can be concluded that the module validation test conducted by one general biology lecturer, one basic chemistry lecturer, one computational physics lecturer, and one science education evaluation lecturer resulted in an average score of 26 , in this case, included in the category high validity so the module can be used. Readability test results are $51.9 \%$; this module has an easy to understand readability level. The results of the posttest test showed that the classical completeness of the experimental class was $82.35 \%$ while the control class was $52.94 \%$. The acquisition of the experimental class is 83.29 , while the control class is 72.94. The experimental class is more effective than the control class. In addition, the results of the gain test and t-test also showed that there were significant differences between the experimental class and the control class of 4.057, and the experimental class gain test $\mathrm{g}=0.31$ and the control class $\mathrm{g}=$ 0.24. Based on the conclusions stated above, to obtain better results in similar studies, it is necessary to pay attention to matters; namely, further research efforts are needed to develop a science-based integrated science digital module for other themes. Due to the limitations of time, in this study researchers only developed a digital science integrated science module based on the topic of Energy, Environment, and Pollution.

\section{References}

Dogruer, N., Eyyam, R., \& Menevis, I. (2011). The use of the internet for educational purposes. Procedia Social and Behavioral Sciences, 28(December), 606-611. https://doi.org/10.1016/j.sbspro.201 1.11.115

Eshet-alkalai, Y. (2004). Digital Literacy:

A Conceptual Framework for Survival Skills in the Digital Era, 13(1), 93-106.

Fatkhurrohman, M. A., \& Astuti, R. K. (2017). Pancasakti Science Education Journal. PSEJ (Pancasakti Science Education Journal), 2(2), 163-171.

Gilster, P., \& Watson, T. (1997). Digital Literacy. Digital Literacy, 20.

Hayati, M. N. (2017). Unnes Science Education Journal. Unnes Science Education Journal, 6(1), 14961502.

Irwandani, I., Latifah, S., Asyhari, A., Muzannur, M., \& Widayanti, W. (2017). Modul Digital Interaktif Berbasis Articulate Studio'13: Pengembangan pada Materi Gerak Melingkar Kelas X. Jurnal Ilmiah Pendidikan Fisika Al-Biruni, 6(2), 
221.

https://doi.org/10.24042/jipfalbiruni. v6i2.1862

Kemenristekdikti. (2018). SELEKSI PUSAT UNGGULAN IPTEK TAHUN 2018, 1.

Lukum, A. (2015). Sains untuk semua.

Matanluk, O., Mohammad, B., Kiflee, D. N. A., \& Imbug, M. (2013). The Effectiveness of Using Teaching Module based on Radical Constructivism toward Students Learning Process. Procedia - Social and Behavioral Sciences, 90(6), 607-615.

https://doi.org/10.1016/j.sbspro.201 3.07.132

Olteanu, R. L., Dumitrescu, C., \& Gorghiu, G. (2014). Studying Sciences through the Integrated Science Modules, 3(3), 35-42. https://doi.org/10.14207/ejsd.2014.v 3n3p35

Oludare Jethro, O., Moradeke Grace, A., \& Kolawole Thomas, A. (2012). ELearning and Its Effects on Teaching and Learning in a Global Age. International Journal of Academic Research in Business and Social Sciences, 2(1), 2222-6990.

PISA. (2012). PISA 2012 Assessment and Analytical Framework PISA 2012 Assessment and Analytical Framework. https://doi.org/http://dx.doi.org/10.1 787/9789264190511-en

Pischetola, M., \& Cattolica, U. (2011). A Research on Sustainable Local Empowerment Digital Media and Learning Evolution :, 11(18), 1-12.

Rusilowati, A. (2014). Analisis Buku Ajar Ipa Yang Digunakan Di Semarang Berdasarkan Muatan Literasi Sains. Prosiding Seminar Nasional Konservasi Dan Kualitas Pendidikan 2014, 6-10.

Sadiman, A., Rahardjo, R., Haryono, A., dan Rahardjito. (1996). Media
Pendidikan. Jakarta: Pustekkom Dikbud dan Raja Grafindo Persada Sahlan, M. \& R. (2013). Pengembangan Instrumen Asesmen Dengan Pendekatan Kontekstual Untuk Mengukur Level Literasi Sains Siswa. Seminar Nasional Evaluasi Pendidikan, 177-190.

Savinainen, A., \& Scott, P. (2002). Using the Force Concept Inventory to monitor student learning and to plan teaching. Physics Education, 37(1), 53-58. https://doi.org/10.1088/00319120/37/1/307

Subekti, H., Taufiq, M., Susilo, H., Ibrohim, \& Suwono, H. (2018). Mengembangkan Literasi Informasi Melalui Belajar Berbasis Kehidupan Terintegrasi STEM untuk Menyiapkan Calon Guru Sains dalam Menghadapi Era Revolusi Industri 4.0: Revieu Literatur. Education and Human Development Journal, 3(1), 81-90.

Yanti, M. (2016). Determinan literasi digital mahasiswa: kasus Universitas Sriwijaya [Determinants of students digital literacy: the case of Sriwijaya University]. Buletin Pos Dan Telekomunikasi, 14(2), 79. https://doi.org/10.17933/bpostel.201 6.140202

Sudijono, A. (2008). Pengantar Statistika Pendidikan. Jakarta: Raja Grafindo.

Sugiyono. (2011). Metode Penelitian Pendidikan: Pendekatan Kuantitatif, Kualitatif dan R \& D. Bandung: Alfabeta

Sugiyono. (2004). Statistik untuk Penelitian.Jakarta: Raja Grafindo 